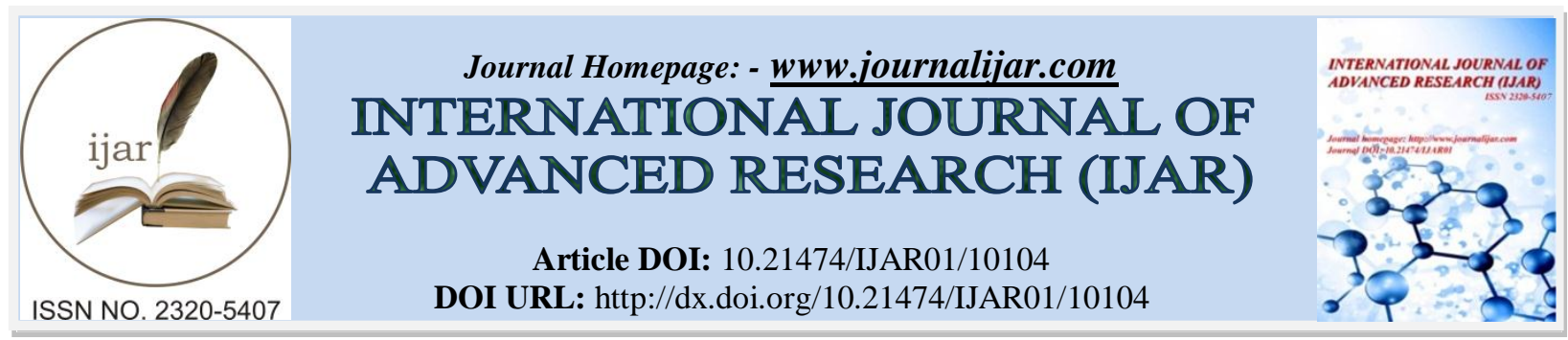

RESEARCH ARTICLE

\title{
BIOCHEMICAL CHANGES IN ZINGIBER OFFICINALE LEAF INFECTED WITH CARBENDAZIM RESISTANT OF PHYLLOSTICTA ZINGIBERI IN WESTERN MAHARASHTRA.
}

\author{
Bharade Sunita Sahaduji. \\ Badrinarayan Barwale College, Jalna. Affiliated to Dr. Babasaheb Ambedkar Marathwada University, \\ Aurangabad,Maharashtra.
}

\section{Manuscript Info}

Manuscript History

Received: 14 September 2019

Final Accepted: 16 October 2019

Published: November 2019

Key words:-

Biochemical, Carbendazim, Leafspot,

Phyllosticta Zingiberi, Zingiber officinale.

\section{Abstract}

Biochemical changes in the mycelia mat of Phyllosticta Zingiberi resistant to carbendazim with 21 parameters viz. starch, reducing sugar, total sugar, polyphenol, DNA, RNA, ash, moisture, nitrogen, phosphorus, potassium, calcium, manganese, sulphur, sodium, zinc,, ferrous copper, mangese, molybdenum, and boron were found to be more in resistant isolates than in sensitive isolates. Thirteen Phyllosticta Zingiberi isolates were obtained from leaf spot of Zingiber officinale and showed 2\% to 9\% minimum Inhibitory Concentration against carbendazim In vitro and In vivo.Infection of Zingiber leaves with resistant and sensitive isolates reduced the contents of all biochemical compounds, due to utilization by fungal pathogen for their growth and metabolism and causes deterioration of the nutrients present in the leaves.

Copy Right, IJAR, 2019,. All rights reserved.

\section{Introduction:-}

Zingiber officinale (Roscoe) is a herbaceous rhizomatous plant of zingiberaceae. It is a perennial flowering plant, whose rhizome is widely used as spices or medicine. (Sood, 2002). Zingiber is the tropical plant. India is the largest producer of it in the world. But it suffers from many diseases and cause substantial yield loss to zingiber production. Leaf spot caused by Phyllosticta Zingiberi Ramkr. is one of the threatening foliar disease and was reported first time in India by Ramkrishnan (1941).

\section{Materials And Methods:}

Leaves of Zingiber infected by leaf spot diseases were collected from different Zingiber growing areas of Kolhapur districts of western Maharashtra state and the pathogen (Phyllosticta Zingiberi ) was isolated by tissue isolation technique and pathogenicity test was confirmed through Koch's postulates, 1893. Baseline sensitivity of Phyllosticta zingiberi to carbendarim was tested by food poisoning technique suggested by (Dekker and Glelink, 1979), a total 13 isolates of Phyllosticta were isolated from Zingiber leaves, from these isolates Jaitpur Pz-11 selected as resistant and Muddal Titta Pz-1 as sensitive.(Table 1.) and used for further studies. For biochemical analysis healthy Zingiber leaves were used. The spore suspension made from actively growing mycelium of Phyllosticta zingiberi was inoculated on the ginger plants and these plants were covered with polythene bags to maintain the relative humidity and to avoid other contamination. After inoculation of 10 days leaves were dried in hot air oven and powder was obtained after crushing in grinder the samples were extracted in ethanol and were analyzed for biochemical estimations (Sindhan and prashar, 1996 ), Altogether twenty parameters were considered

Corresponding Author:-Bharade Sunita Sahaduji.

Address:-Badrinarayan Barwale College, Jalna. Affiliated to Dr. Babasaheb Ambedkar Marathwada 
for analysis viz, Nitrogen(Bailey,1967),starch, sugars and total sugars(Sridhar and Du,1974), Nucleic acids DNA and RNA ( Plummer 1975), Polyphenols (Swain and Hillis,1959),Ash, Moisture,Phosporus, potassium, calcium, magnesium, sulphur, and sodium ( A.O.A.C. ,1970), Zinc, Ferrous, Copper, Mangnese, Molybdenum, and Boron (A.O.A.C., 1975)

\section{Result and Discussion:-}

Biochemical analysis of spore suspension of carbendazim resistant and sensitive Phyllosticta zingiberi strains are shown in Table 2. It was noted that the content of 21 parameters in the suspension varied in sensitive and resistant strains. Reducing sugar, total sugar,Polyphenols, were found to be higher in their quantity in carbendazim resistant strain when compared with the sensitive one. Nitrogen were found to be more in sensitive strain than in resistant one. Variatations were observed in all biochemical studies in infected leaves with carbendazim resistant and sensitive strains and healthy Zingiber leaves. But amount of starch is more in sensitive than the resistant. The amount of Phophorus is equal in healthy, sensitive and resistant strains. The results of remaing parameters are showed in ( Table 2.) There are reports supporting the characteristics of resistant isolate. According to Rana and Sengupta (1976) there was increase in production of amino acids in the isolate of Macrophomina phseolina resistant to captan and carbendazim. There are many reports indicating changes in the biochemical characteristic in host due to infection of various pathogens, (Gangawane and Datar, 1978),Salt et al., 1978), (Sindhan and Parashar, 1996. According to) the concentration of total sugar, reducing sugrs, non reducing sugars, reducing sugars and proteins were reduced due to infection of seed borne fungi of cowpea (Ushamalini et al., 1998).

Table 1. MIC (Minimum Inhibitory Concentration ) of carbendazim against Phyllosticta zingiberi causing leaf spot of Zingeiber officinale

\begin{tabular}{|c|c|c|c|c|}
\hline Sr.No. & Locality & Isolate & In Vitro (\% Carbendazim) & In Vivo (\% Carbendazim) \\
\hline 1 & *Mudal Titta & Pz-1 & 2 & 2 \\
\hline 2 & Majnal & $\mathrm{Pz}-2$ & 4 & 4 \\
\hline 3 & Kolhapur & $\mathrm{Pz}-3$ & 5 & 4 \\
\hline 4 & Mangnur & $\mathrm{Pz}-4$ & 3 & 2 \\
\hline 5 & Mhalunge & Pz-5 & 6 & 5 \\
\hline 6 & Jambhli & Pz-6 & 6 & 4 \\
\hline 7 & Zelam & Pz-7 & 3 & 3 \\
\hline 8 & Islampur & $\mathrm{Pz}-8$ & 5 & 3 \\
\hline 9 & Dahiwadi & Pz-9 & 7 & 5 \\
\hline 10 & Koregaon & $\mathrm{Pz}-10$ & 4 & 3 \\
\hline 11 & *Jaitpur & Pz-11 & 9 & 8 \\
\hline 12 & Vadiye Raybag & $P z-12$ & 5 & 4 \\
\hline 13 & Tandulwadi & $P z-13$ & 8 & 5 \\
\hline
\end{tabular}

Table2. Biochemical Characteristics of the ginger leaves infected with sensitive and resistant Isolates.

\begin{tabular}{|c|l|l|l|l|}
\hline Sr.No. & Biochemical Constituents & $\begin{array}{l}\text { Healthy } \\
\text { Ginger } \\
\text { leaves }\end{array}$ & $\begin{array}{l}\text { Ginger leaves } \\
\text { infected with } \\
\text { Sensitive isolates }\end{array}$ & $\begin{array}{l}\text { Ginger leaves } \\
\text { infected with } \\
\text { Resistant isolates }\end{array}$ \\
\hline 1 & Starch (g/10Ogdry wt) & 1.758 & 1.581 & 1.409 \\
\hline 2 & Reducing sugar (g/100gdry wt) & 0.180 & 0.146 & 0.162 \\
\hline 3 & Total sugar (g/100gdry wt) & 0.079 & 0.077 & 0.033 \\
\hline 4 & Polyphenol (g/1OOgdry wt) & 0.406 & 0.508 & 0.538 \\
\hline 5 & DNA (mg/g) & 0.189 & 0.152 & 0.145 \\
\hline 6 & RNA(mg/g) & 0.043 & 0.140 & 0.135 \\
\hline 7 & Ash (\%) & 7.70 & 8.20 & 9.80 \\
\hline 8 & Moisture (\%) & 6.30 & 6.60 \\
\hline 9 & Nitrogen (\%) & 0.78 & 0.39 \\
\hline 10 & Phosphorous (\%) & 0.01 & 0.01 \\
\hline 11 & Potassium (\%) & 0.048 & 0.051 \\
\hline 12 & Calcium (\%) & 0.44 & 0.70 \\
\hline 13 & Magnesium (\%) & 0.01 & 1.70 \\
\hline 14 & Sulphur (\%) & 0.079 & 0.55 \\
\hline 15 & Sodium (\%) & 1.09 & 0.45 & 1.34 \\
\hline 16 & Zinc (ppm) & 2.65 & 1.26 & 32.36 \\
\hline 17 & Ferrous (ppm) & 0.45 & 30.46 & 34.60 \\
\hline 18 & Copper (ppm) & 32.64 & 18.36 \\
\hline 19 & Mangnese (ppm) & 4.00 & 48.55 \\
\hline
\end{tabular}




\section{References:-}

1. A.O.A.C. (1975). Official and tentative methods of Analysis, Association of official Agricultural chemists, Inc. Washington 4 D.C.

2. A.O.A.C. 197. Official method of Analysis. $11^{\text {th }}$ Edn. Association of Official Analytical Chemists, Washington, D.C.

3. Bailey, B.L. (1967). Techniques in protein chemistry $2^{\text {nd }}$ Edn. Elsevier Publishing Co., Amsterdam.

4. Dekker, J. (1982). Introduction to course on fungicide resistance. In: fungicide resistance in crop protection Dekker J. and Georgopoulos, S.G. Eds. C.A.D.P Wageningen, Netherlands. pp. 128-123.

5. Dekker, J. and Glelink, A.J. (1979a \& b). Acquired resistance to pimaracin in Cladosporium cucumarinum and Fusarium oxysporum f. sp. narcissi associated with decreased virulence. Neth. J. Plant. Pathol. 85: 67-73.

6. Gangawane, L.V. and Datar, V.V. (1978). Ascorbic acid content of healthy and infected tomato Alternaria solani germplasm. Ind. Phytopath. 31(2): 237-238.

7. Koch, R. (1893). "On the current state of Bacteriological cholera diagnosis" [About the instantaneous state of the bacteriological diagnosis of cholera]. Journal of Hygine and Infectious Diseases (in German) $14: 319-38$.

8. Plummer, D.T. (1975). An introduction to practical Biochemistry. Tata McGraw Hill Publishers Ltd., 215-216.

9. Ramkrishnan T.S, (1941). A leaf spot disease of Zingiber officinale caused by Phyllosticta Zingiberi Proceeding of Indian Academi of sciences-section B15(4) 167-771.

10. Rana, J.P. and Sengupta, P.R.(1976). Increased production of some Amino acids : A possible mechanism for mercury and captan tolerance by fungicide adopted isolates of Macrophomina phaseolina. Acta phytopathol. Acad. Sci. Hung. 11: 65-70.

11. Salt, S.D., Pan, S.Q. and Kuc, J. (1978). Carbohydrate changes in tobacco systematically protected against blue mold by stem infection with Perenospora tabacina. Phytopathology, 78:733-738

12. Sindhan, G.S. and Parshar (1996). Biochemical changes in groundnut leaves due to infection by early and late leaf spot pathogen. Indian J. Mycol. Pl. Pathol. Vol. 26(2), 210-212

13. Sirdhar, R. And Du. S. H. (1974). Phytopathology 2:222

14. Sood, (2002). Studies on leaf spot of ginger caused by Phyllosticta zingiberi Ramkr. M.Sc. Thesis "Dr. V.S. Parmar University of Horticulture and Forestry". Nauni, Solan (H.P.) India.

15. Swain, T. and Hillis, W.E. (1959). The phenolic estimation of Prunus domestics I. The qualitative analysis of phenolic compound Jr. Sci. Food. Agri. 10:63-68.

16. Ushamalini, C. K.Rajappan and Rousalya Gangadharan (1998). Changes in the biochemical constitutes of cowpea due to seed borne fungi. Indian phytopath.51 (3):258-260. 